\title{
New combinations in Guilandina (Leguminosae: Caesalpinioideae)
}

\section{G. P. Lewis ${ }^{1}$}

Summary. The Caesalpinia Group (Leguminosae: Caesalpinioideae) and the genus Caesalpinia sensu lato were recently reclassified resulting in a reduction in the number of species in Caesalpinia sensu stricto to nine. Of the genera now accepted as distinct from Caesalpinia, the pantropical genus Guilandina lacks any recent global taxonomic account and estimates of the number of species in the genus range from seven to as many as 20. Seven putative species are currently known only under Caesalpinia binomials and have no published combination in Guilandina. This inconvenience is rectified here. Putting these binomials into the correct genus will ensure that they are not overlooked in any future revision of Guilandina, a genus of taxonomic complexity and including some nomenclatural conundrums.

Key Words. Fabaceae, nomenclature.

\section{Introduction}

Up to the turn of the last millennium, the genus Caesalpinia, as traditionally circumscribed, comprised between 120 and 130 species and included 25 generic names in synonymy (Lewis 1998). A series of publications (Lewis \& Schrire 1995; Ulibarri 1996, 2008; Simpson \& Miao 1997; Lewis 1998, 2005; Simpson 1998, 1999; Bruneau et al. 2001, 2008; Herendeen et al. 2003; Simpson \& Lewis 2003; Simpson et al. 2003; Simpson \& Ulibarri 2006; Manzanilla \& Bruneau 2012; Gagnon et al. 2013, 2015; Clark \& Gagnon 2015; Clark 2016) culminating in A New Generic System for the Pantropical Caesalpinia Group (Gagnon et al. 2016) have successively revealed that several names synonymised under Caesalpinia sensu lato needed to be reinstated as distinct genera, and that other unique species, or small clusters of taxa, required new generic status.

The genus Guilandina L. was first described by Linnaeus (1753) but subsequently most studies have considered it to be synonymous with or a subgenus of Caesalpinia, although some authors have continued to consider it to be a distinct genus (e.g., Britton \& Rose 1930; Lewis 2005), while others have implied that it should be reinstated at separate genus rank (e.g., Verdcourt 1979). Chemical analyses (Kite \& Lewis 1994), a unique suite of morphological characters (including paribipinnate leaves armed with recurved prickles, unisexual flowers on separate male and female racemes, sepals valvate in bud, inflated pods usually clothed in robust trichomes, and ovoid to globular, smooth seeds with parallel fracture lines concentric with a small apical hilum; Gagnon et al. 2016) together with molecular studies (Gagnon et al. 2013, 2016), all support recognition of Guilandina as distinct from Caesalpinia sensu stricto. By morphological comparison with Guilandina, Caesalpinia s.s. species are shrubs or small trees (vs lianas or scrambling shrubs), have bisexual (vs unisexual) flowers, sepals imbricate (vs valvate) in bud, petals barely extending beyond the sepals (vs evidently longer), laterally compressed, unarmed pods (vs inflated pods usually armed with robust spinescent bristles) and compressed (vs globose) seeds.

Guilandina has a pantropical distribution, occurring as far north as Japan and as far south as South Africa. The hard, marble-shaped seeds can drift on ocean currents and arrive on island beaches and continental shores. Ten species (or more precisely binomials) occur in the Caribbean, nine are endemic to various island groups in the region (Acevedo-Rodríguez \& Strong 2012). Pending a global revision of the genus, the exact total number of species remains uncertain. Here, added to the list of 19 names included under Guilandina by Gagnon et al. (2016) is Caesalpinia robusta (C.T.White) Pedley (Pedley 1977), endemic to Queensland, Australia. This is one of seven Caesalpinia names which belong in Guilandina but have yet to receive a published combination in that genus. To ensure that these names are not overlooked in any future revision of Guilandina, new combinations for these seven names are presented below, and it is likely that most, if not all, of these will retain their species status after scrutiny.

\section{New combinations}

Herbarium acronyms follow Index Herbarionum (Thiers n.d. continuously updated).

\section{Guilandina delphinensis (Du Puy $\mathcal{E}$ R.Rabev.) G.P.Lewis, comb. nov.}

http://www.ipni.org/urn:lsid:ipni.org:names:77204841-1

\footnotetext{
Accepted for publication 28 January 2020. Published online 29 April 2020

1 Comparative Plant and Fungal Biology Department, Royal Botanic Gardens, Kew, Richmond, Surrey, TW9 3AB, UK. e-mail: G.Lewis@kew.org
} 
Caesalpinia delphinensis Du Puy \& R.Rabev., in Du Puy et al., The Leguminosae of Madagascar: 47 (2002). Type: SE Madagascar, Fort Dauphin [Taolañaro], Alluaud 3 (holotype: P).

Guilandina homblei (R. Wilczek) G.P.Lewis, comb. nov. http:/ /www.ipni.org/urn:lsid:ipni.org:names:77204842-1

Caesalpinia homblei R. Wilczek, Bull. Jard. Bot. État. Bruxelles 21: 85 (1951). Type: Democratic Republic of the Congo [Belgian Congo]: Upper Katanga Distr. [Haut-Katanga], Homblé 88 (holotype: BR).

\section{Guilandina minax (Hance) G.P.Lewis, comb. nov.}

http:/ /www.ipni.org/urn:lsid:ipni.org:names:77204843-1

Caesalpinia minax Hance, J. Bot. 22: 365 (1884). Type: China, "juxta oppidum Shiu-hing, secus fl. North River, prov. Cantonensis, detexit rev. R. H. Graves (Herb. propr. n. 22284)", type not traced, n.v.

Caesalpinia morsei Dunn, J. Linn. Soc., Bot. 35: 492 (1903). Type: China, Kwangsi, Lungchow, H. B. Morse 303 (lectotype: K!, barcode: K00544235, here designated, flowering specimen; isolectotype: a second sheet of Morse 303 at K!,barcode: K000789324, in flower and immature fruit, but lacking locality data); Other original material: China, Yunnan, Szemao, north-west mountains, A. Henry 10739 (K!, barcode: K000789325); Vietnam, Tonkin, B. Balansa 2145 (K!, barcode: K000789321).

Guilandina murifructa (Gillis E $\mathcal{F}^{2}$ Proctor) G.P.Lewis, comb. nov.

http:/ /www.ipni.org/urn:lsid:ipni.org:names:77204844-1

Caesalpinia murifructa Gillis \& Proctor, J. Arnold Arbor. 55: 427 (1974). Type: Bahamas: Great Inagua Island, Matthew Town, Proctor $\mathcal{E}$ Gillis 33371 (holotype: A, photo K!; isotypes: IJ, BM).

Guilandina robusta (C.T.White) G.P.Lewis, comb. nov.

http:/ /www.ipni.org/urn:lsid:ipni.org:names:77204845-1

Caesalpinia robusta (C.T.White) Pedley, Austrobaileya 1: 34 (1977).

Mezoneuron robustum C.T.White, Contr. Arnold Arbor. 4: 43 (1933). Type: Australia, Queensland, Atherton Tableland, Boonjie, S. F. Kajewski 1206 (holotype: BRI; isotype: $\mathrm{K}$ !, barcode: K000264159).
Guilandina solomonensis (Hattink) G.P.Lewis, comb. nov.

http:/ /www.ipni.org/urn:lsid:ipni.org:names:77204846-1

Caesalpinia solomonensis Hattink, Reinwardtia 9 (1): 54 (1974). Type: E. Malesia, Solomon Ils., SE New Georgia, Viru R., L. Maenu' u BSIP 6068 (holotype: L; isotypes: HON, K!, barcode: K000789388, LAE, SING, US).

Guilandina volkensii (Harms) G.P.Lewis, comb. nov.

http:/ /www.ipni.org/urn:lsid:ipni.org:names:77204847-1

Caesalpinia volkensii Harms, Bot. Jahrb. Syst. 45 (2): 304 (1910). Type: Tanzania, Lushoto Distr., Kwa Mshusa, Handei, C. Holst 9123 (lectotype: K!, barcode: K000544234, here designated; isolectotype: $\mathrm{B} \uparrow$ ); Other original material: Moshi Distr., Marangu, G. Volkens 1454 ( $\mathrm{B} \dagger)$; Moshi, Merker 509 (B十, BM, drawing); Amani, Monga, Braun 1549 (B†, EA).

\section{Acknowledgements}

Thanks to Heather Lindon for checking the nomenclature, Ruth Linklater and Bente Klitgård for commenting on the first draft of this article and two anonymous reviewers for their helpful remarks.

Open Access This article is licensed under a Creative Commons Attribution 4.0 International License, which permits use, sharing, adaptation, distribution and reproduction in any medium or format, as long as you give appropriate credit to the original author(s) and the source, provide a link to the Creative Commons licence, and indicate if changes were made. The images or other third party material in this article are included in the article's Creative Commons licence, unless indicated otherwise in a credit line to the material. If material is not included in the article's Creative Commons licence and your intended use is not permitted by statutory regulation or exceeds the permitted use, you will need to obtain permission directly from the copyright holder. To view a copy of this licence, visit http://creativecommons.org/ licenses/by/4.0/.

\section{References}

Acevedo-Rodríguez, P. \& Strong, M. T. (2012). Catalogue of Seed Plants of the West Indies. Smithsonian Contr. Bot. 98: 434.

Britton, N. L. \& Rose, J. N. (1930). Caesalpiniaceae, Krameriaceae, (Rosales). N. Amer. Fl. 23: 301 - 342.

Bruneau, A., Herendeen, P. S., Klitgaard, B. B. \& Lewis, G. P. (2001). Phylogenetic relationships in the 
Caesalpinioideae (Leguminosae) as inferred from chloroplast trnL intron sequences. Syst. Bot. 26: 487 - 514.

, Mercure, M., Lewis, G. P. \& Herendeen, P. S. (2008).

Phylogenetic patterns and diversification in the Caesalpinioid legumes. Botany 86: 697 - 718.

Clark, R. P. (2016). A taxonomic revision of Mezoneuron (Leguminosae: Caesalpinioideae: Caesalpinieae). Phytotaxa 274(1): 1 - 72.

\& Gagnon, E. (2015). A revision of Mezoneuron (Leguminosae: Caesalpinioideae) in New Caledonia, with perspectives on vegetation, geology, and conservation. Phytotaxa 207(1): 68 - 92.

Dunn, S. T. (1903). Descriptions of new Chinese plants, chiefly by S.T. Dunn, with an introductory note by Charles Henry Wright. J. Linn. Soc., Bot. 35: 483-518.

Du Puy, D. J., Labat, J.-N., Rabevohitra, R., Villiers, J.F., Bosser, J. \& Moat, J. (2002). The Leguminosae of Madagascar. Royal Botanic Gardens, Kew.

Gagnon, E., Hughes, C. E., Lewis, G. P. \& Bruneau, A. (2015). A new cryptic species in a new cryptic genus in the Caesalpinia group (Leguminosae) from the seasonally dry inter-Andean valleys of South America. Taxon 64(3): $468-490$.

, Lewis, G. P., Sotuyo, J. S., Hughes, C. E. \& Bruneau, A. (2013). A molecular phylogeny of Caesalpinia sensu lato: Increased sampling reveals new insights and more genera than expected. S. African J. Bot. 89: 111 - 127.

, Bruneau, A., Hughes, C. E., de Queiroz, L. P. \& Lewis, G. P. (2016). A new generic system for the pantropical Caesalpinia Group (Leguminosae). PhytoKeys 71: 61 - 65.

Gillis, W. T. \& Proctor, G. R. (1974). Caesalpinia subgenus Guilandina in the Bahamas. J. Arnold. Arbor. 55: 425 - 430.

Hance, H. F. (1884). Four new Chinese Caesalpinieae. J. Bot. 22: $365-366$.

Harms, H. (1910). Leguminosae africanae V. Bot. Jahrb. Syst. 45(2): $293-316$.

Hattink, T. A. (1974). A revision of Malesian Caesalpinia including Mezoneuron (LeguminosaeCaesalpiniaceae). Reinwardtia 9(1): 1 - 69.

Herendeen, P. S., Bruneau, A. \& Lewis, G. P. (2003). Phylogenetic relationships in caesalpinioid legumes: a preliminary analysis based on morphological and molecular data. In: B. Klitgaard \& A. Bruneau (eds), Advances in Legume Systematics, Part 10: Higher Level Systematics, pp. 37 - 62. Royal Botanic Gardens, Kew.

Kite, G. C. \& Lewis, G. P. (1994). Chemotaxonomy of seed non-protein amino acids in Caesalpinia s.l. In: J. I. Sprent \& D. McKey (eds), Advances in Legume Systematics, Part 5: The Nitrogen Factor, pp. 101 - 105. Royal Botanic Gardens, Kew.

Lewis, G. P. (1998). Caesalpinia: a revision of the Poincianella-Erythrostemon group. 1 - 233. Royal Botanic Gardens, Kew.

(2005). Tribe Caesalpinieae. In: G. Lewis, B. Schrire, B. Mackinder \& M. Lock (eds), Legumes of the World, pp. 127 - 159. Royal Botanic Gardens, Kew.
\& Schrire, B. D. (1995). A reappraisal of the Caesalpinia group (Caesalpinioideae: Caesalpinieae) using phylogenetic analysis. In: M. D. Crisp \& J. J. Doyle (eds), Advances in Legume Systematics, Part 7: Phylogeny, pp. 41 - 52. Royal Botanic Gardens, Kew.

Linnaeus, C. (1753). Species Plantarum 1: 381. Laurentius Salvius, Stockholm.

Manzanilla, V. \& Bruneau, A. (2012). Phylogeny reconstruction in the Caesalpinieae grade (Leguminosae) based on duplicated copies of the sucrose synthase gene and plastid markers. Molec. Phylogenet. Evol. 65: 149 - 162.

Pedley, L. (1977). Caesalpinia robusta (C.T.White) Pedley. Austrobaileya 1: 34.

Simpson, B. B. (1998). A revision of Pomaria (Fabaceae) in North America. Lundellia 1: 46 - 71. (1999). A revision of Hoffmannseggia (Fabaceae) in North America. Lundellia 2: $14-54$.

\& Lewis, G. P. (2003). New combinations in Pomaria (Caesalpinioideae: Leguminosae). Kew Bull. 58(1): $175-184$.

\& Miao, B. M. (1997). The circumscription of Hoffmannseggia (Fabaceae, Caesalpinioideae, Caesalpinieae) and its allies using morphological and cpDNA restriction site data. Pl. Syst. Evol. 205: 157 - 178.

\& Ulibarri, E. A. (2006). A synopsis of the genus Hoffmannseggia (Leguminosae). Lundellia 9: 7 - 33.

, Larkin, L. \& Weeks, A. (2003). Progress towards resolving the relationships of the Caesalpinia group (Caesalpinieae: Caesalpinioideae: Leguminosae). In: B. Klitgaard \& A. Bruneau (eds), Advances in Legume Systematics, Part 10: Higher Level Systematics, pp. 123 - 148. Royal Botanic Gardens, Kew.

Thiers, B. (n.d.). [continuously updated]. Index Herbariorum: A global directory of public herbaria and associated staff. New York Botanical Garden's Virtual Herbarium. Published at: http:/ /sweetgum.nybg.org/ih/

Ulibarri, E. A. (1996). Sinopsis de Caesalpinia y Hoffmannseggia (Leguminosae-Caesalpinioideae) de Sud América. Darwiniana 34 (1 - 4): 299 - 348.

(2008). The genera of Caesalpinioideae (Leguminosae) from South America. Darwiniana 46(1): 69 - 163.

Verdcourt, B. (1979). A manual of New Guinea Legumes, Vol. 11: 20 - 29. Office of Forests, Division of Botany, Lae, Papua New Guinea.

White, C. T. (1933). Ligneous plants collected for the Arnold Arboretum in North Queensland by S.F. Kajewski in 1929. Contr. Arnold Arbor. 4: 5-101.

Wilczek, R. (1951). Deux nouvelles especes de Caesalpinia du Congo Belge. Bull. Jard. Bot. Brux. 21: $83-86$.

\section{Publisher's Note}

Springer Nature remains neutral with regard to jurisdictional claims in published maps and institutional affiliations. 